\title{
An Empirical Investigation of Tourism-Led Growth Hypothesis in the European Countries: Evidence from Augmented Mean Group estimator
}

\begin{abstract}
Due to urbanization and the need for people to go from one country to another either for commercial purpose or tourism, it is therefore important to determine the extent to which tourism contributes to growth. This article aims to investigate the tourism-led growth hypothesis in a sample of 34 European countries utilizing the yearly data from 1995 to 2015. The research work makes use of 8 tourism indicators, which cover different dimensions of tourism sector development such as foreign visitors' spending, and international tourist arrival. For empirical analysis, the study accounts key determinants of growth such as capital, labor and energy (renewable and non-renewable) consumption. The results from common correlated effects (CCE) augmented mean group (AMG) and groped-mean estimators confirms that there is a positive relationship between tourism, labour, capital and GDP insinuating the presence of tourism-led growth hypothesis in the European countries. Also, findings from the FMOLS show that changes in the variables leads to a proportional change in GDP. Specifically, the evidence shows that the tourism indicators play an indispensable role in promoting economic development, along with energy consumption, capital, and labor. Sustainable Combating environmental issues associated with foreign arrivals, renewable energy consumption should be encouraged to reduce environmental externalities to ensure sustainable environments for businesses and tourists arrivals. The study offers numerous policy and practical implications.
\end{abstract}

Keywords: Tourism; growth; European countries; energy consumption; AMG estimator JEL classification: L16; O4; E32; C22 


\section{Introduction and contribution}

During the past decade, most of the European countries have been struggling to overcome the economic difficulties caused by the global financial crisis of 2008. The global financial crisis happened 11 years ago, while several countries of Europe are still struggling for economic development or facing economic recession e.g., Greece, Croatia, Italy, and Spain, etc. (Gibson, Hall and Tavlas, 2012; Smith, 2016). Meanwhile, the economic recession and problems further caused disturbing political outcomes in European Union (EU): referendum in the United Kingdom (Brexit issue), where the UK United Kingdom choose to leave the EU (Bourne, 2016; Dogru \& Bulut, 2018). The economic downturn has affected almost all the sectors in the economy, including manufacturing, agriculture, trade, and tourism, etc. Surprisingly, the tourism sector exposed as the fastest growing industry and sustainable growth in the past two decades in most European countries. With the global boom of the tourism sector, most of developing, emerging and developed countries have realized the importance of the tourism sector for economic growth. Accordingly, several research scholars, economists, and policymakers have focused on the tourism sector to consider it as recovery engine for economic development, as tourism led growth policies are becoming a critical concern for developing and developed countries (Gibson, Hall and Tavlas, 2012; Pipike, 2012; Liu et al., 2015; Tang and Tan, 2015; Rivera, 2017; Ohlan, 2017; Fahimi et al., 2018; Dogru and Bulut, 2018; Corbet et al., 2019).

According to the World Travel and Tourism Council, tourism is one of the largest commercial industry. Tourism sector contribution to the economy is impressive: the tourism industry accounts for 9 per cent of global GDP, with a volume of more than US $\$ 6$ trillion by providing 255 million jobs (WTTS, 2011). As per economic forecasting, the tourism sector is expected to have 4 percent annual growth; this might bring it up to 10 percent of global GDP or about US $\$ 10$ trillion (Chou, 2013; Liu et al., 2015). Notably, the European region is known as a prominent tourist destination for travelling aspirants, 
accounting for 713 million tourist arrivals in 2018 with 6 percent growth from 2017 (UNWTO, 2019).

According to world tourism annual reports, European countries are among the top-ranked in tourism ranking over the past few years: in 2017, the tourist arrivals of European countries were 672 million people with revenue of US\$ 519 billion (UNWTO, 2018). Due to such facts, the European Union has placed much attention on the tourism sector as an instrument of economic development (Chou, 2013; Liu et al., 2015). Figure 1(a, b) and Table 1 highlights the tourism indicators outlook and economic growth of 34 sample countries of Europe. Figure 1 depicts that European countries enjoy 39\% of tourism revenue, with $50 \%$ of the world's total tourist arrivals.

Table 1: Tourism outlook and economic growth of European countries (2015 facts)

\begin{tabular}{|l|l|l|l|l|l|l|}
\hline Sr \# & Country & $\begin{array}{l}\text { Tourism } \\
\text { rank }\end{array}$ & $\begin{array}{l}\text { Business tourism } \\
\text { spending } \\
\text { \$ real prices) }\end{array}$ & $\begin{array}{l}\text { Tourism contribution } \\
\text { to GDP (US \$ real } \\
\text { prices) }\end{array}$ & $\begin{array}{l}\text { Tourist } \\
\text { arrivals } \\
\text { (persons) }\end{array}$ & $\begin{array}{l}\text { GDP } \\
\text { growth } \\
\%\end{array}$ \\
\hline 1 & Albania & 58 & 814 & 3472.66 & 3784000 & 2.23 \\
\hline 2 & Armenia & 104 & 196.11 & 1518.44 & 1192000 & 3.20 \\
\hline 3 & Austria & 12 & 7036 & 63880.1 & 26728000 & 1.14 \\
\hline 4 & Belarus & 168 & 1052.38 & 3226.16 & 4385600 & -3.8 \\
\hline 5 & Belgium & 39 & 6521.54 & 29723.6 & 8355000 & 1.74 \\
\hline 6 & Bulgaria & 42 & 1292.02 & 6303.33 & 7099000 & 3.47 \\
\hline 7 & Croatia & 25 & 1015 & 13036.8 & 12683000 & 2.40 \\
\hline 8 & Cyprus & 64 & 255.29 & 4067.48 & 2659000 & 1.96 \\
\hline 9 & Czech Republic & 36 & 2217 & 16759.7 & 8707000 & 5.31 \\
\hline 10 & Denmark & 28 & 7420 & 24900.1 & 10424000 & 2.34 \\
\hline 11 & Estonia & 67 & 672 & 4097.04 & 2961000 & 1.90 \\
\hline 12 & Finland & 75 & 4681 & 22199.6 & 2622000 & 0.50 \\
\hline 13 & France & 1 & 38764 & 252020 & 84452000 & 1.11 \\
\hline 14 & Germany & 7 & 57242 & 327350 & 34970000 & 1.74 \\
\hline 15 & Greece & 15 & 1884 & 40215.8 & 23599000 & -0.5 \\
\hline 16 & Hungary & 55 & 1038.21 & 10899.2 & 4929000 & 3.54 \\
\hline 17 & Iceland & 100 & 913.46 & 6920.46 & 1289000 & 4.47 \\
\hline 18 & Ireland & 33 & 4640 & 18677.9 & 9528000 & 25.1 \\
\hline 19 & Italy & 5 & 38428 & 256032 & 50732000 & 0.92 \\
\hline 20 & Latvia & 81 & 388.65 & 2896.55 & 2024000 & 2.97 \\
\hline 21 & Lithuania & 78 & 546.32 & 2252.76 & 2071000 & 2.02 \\
\hline 22 & Netherlands & 22 & 10035 & 42941 & 15007000 & 1.96 \\
\hline 23 & Norway & 50 & 5489.28 & 34814.4 & 5361000 & 1.97 \\
\hline 24 & Poland & 20 & 4438.65 & 22736.2 & 16728000 & 3.84 \\
\hline & & & & & \\
\hline
\end{tabular}




\begin{tabular}{|l|l|l|l|l|l|l|}
\hline 25 & Portugal & 32 & 4678 & 38130.2 & 11723000 & 1.82 \\
\hline 26 & Romania & 34 & 2196.36 & 11094.8 & 9331000 & 3.87 \\
\hline 27 & Slovak Republic & 87 & 1486 & 5962.19 & 1721000 & 4.17 \\
\hline 28 & Slovenia & 72 & 635.24 & 5875.57 & 2707000 & 2.30 \\
\hline 29 & Spain & 3 & 15955 & 186681 & 68175000 & 3.64 \\
\hline 30 & Sweden & 43 & 11414 & 47254.4 & 6482000 & 4.46 \\
\hline 31 & Switzerland & 35 & 6906 & 57163 & 9305000 & 1.33 \\
\hline 32 & Turkey & 6 & 7007 & 83286.7 & 39478000 & 6.09 \\
\hline 33 & Ukraine & 23 & 554 & 6190.58 & 12428000 & -9.7 \\
\hline 34 & United Kingdom & 8 & 66410 & 272912 & 34436000 & 2.35 \\
\hline
\end{tabular}

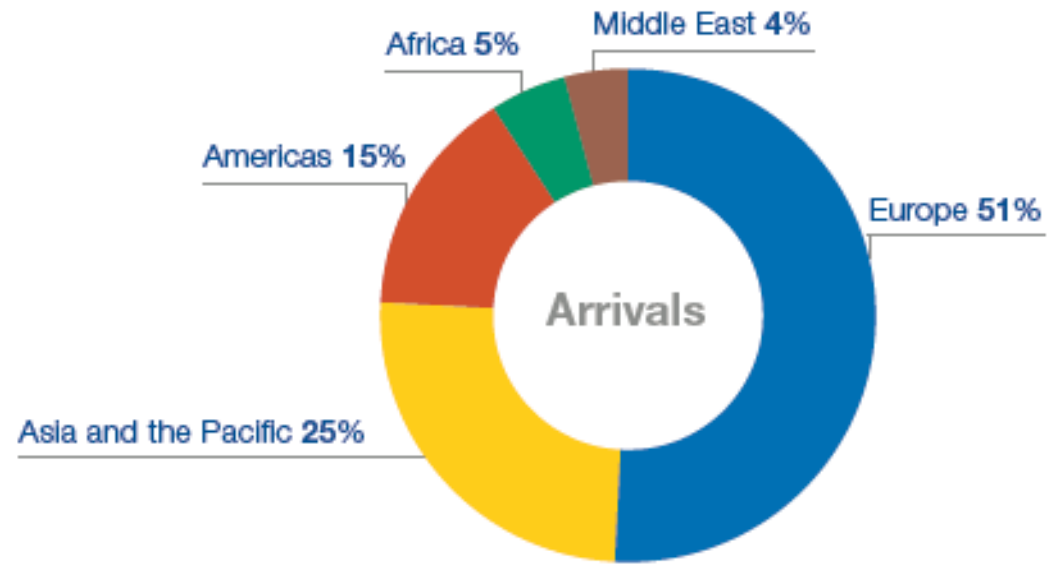

Figure 1(a): Tourist arrivals in Europe 2019 estimates

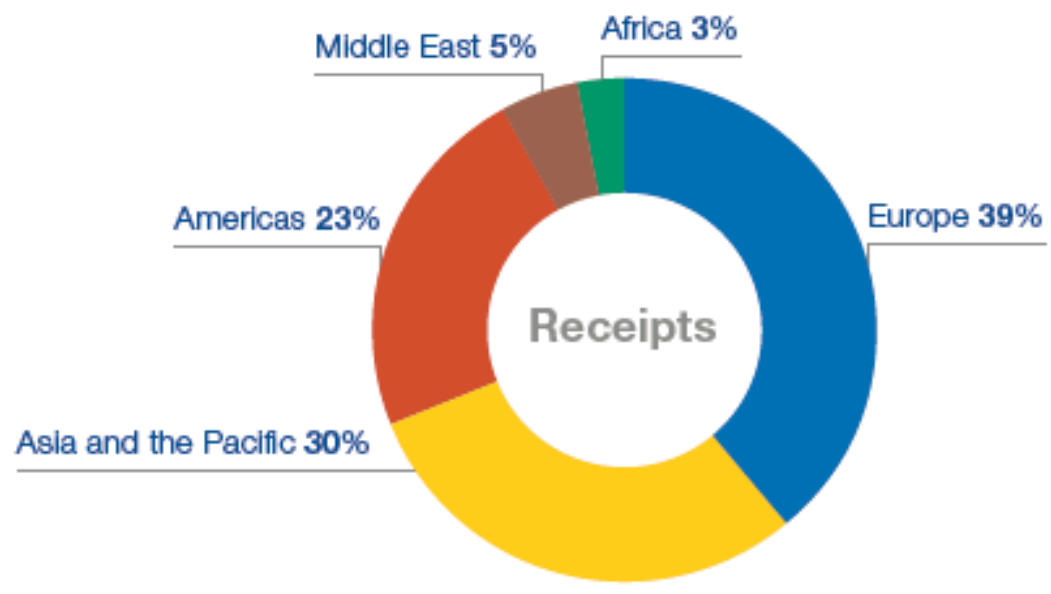

Figure 1 (a, b): Tourist arrivals and tourism revenue of Europe in 2019

UNWTO, (2019)

Given these facts, the tourism industry contributes in multi-directions for economic development e.g. revenue generation, jobs creation and entrepreneurial vitality 
etc. Furthermore, the tourism sector has been established as a popular strategy for economic development in developing, emerging and developed countries (Andereck et al., 2005; Matarrita-Cascante, 2010; Romero and Molina, 2013; Jones and Li, 2015; Li, Jin and Shi, 2018; Lanouar and Goaied, 2019).

The existing literature has indicated several factors as contributing factor of economic growth which includes; exports, international trade, FDI, employment, industrialization, agriculture sector, capital, tourism, labor and technology etc (Adedoyin, Bekun, Driha, \& Balsalobre-Lorente, 2020; Severn, 1968; Balaguer and Cantavella-Jordá, 2002; Durbarry, 2004; Bhorat, Cassim and Tseng, 2016; Shahbaz et al., 2017; Shahzad et al., 2019). Inconsistent with the export-led growth hypothesis, the tourism-growth narrative might postulate the existence of various arguments for which the tourism industry might become an essential determinant for long-run economic progress. The research scholars and economists have tested the tourism-growth hypothesis for the case of developing and developed nations (Liu et al., 2015; Rivera, 2017; Li, Jin and Shi, 2018; Lanouar and Goaied, 2019). Although tourism is argued to influence the environment (Adedoyin \& Bekun, 2020; Adedoyin, Nathaniel, \& Adeleye, 2020), in a general sense, the tourism sector brings more foreign exchange revenue, which can be used in the import of capital goods for producing goods and services in objective to achieve higher economic growth. Notably, the tourism industry provides a remarkable part of the financing to host economy to import more than its exports. However, if the imports are capital and basic materials for the production of goods in an economy, then it can be argued that tourism revenue instigates to improve economic development. In such a scenario, the non-tourist regions in a country might also benefit from tourism revenue as a result of the distribution of a country's wealth (Balaguer \& Cantavella-Jordá, 2002). In addition, the international tourism positively contributes to increase the income level in two ways: first, the tourism revenue might enhance efficiency through competition between local firms (restaurants, tourist planners, hotels etc.) and the one's corresponding 
to foreign tourist destinations1. Secondly, the tourism industry helps in the economy of scale in local firms (Balaguer and Cantavella-Jordá, 2002).

The prime objective of this article is to conduct an empirical investigation into tourism led growth hypothesis for European countries. Accordingly, the paper aims to provide innovative and fruitful implications concerning the tourism industry and economic development of the European region.

This article reports three important innovations in the academic literature, which are different from the existing research on tourism and economic growth. First, we used eight key indicators of tourism as a proxy for tourism development, which has been ignored in previous studies. The existing research (Tang and Tan, 2013; Aslan, 2016; Fahimi et al., 2018; Gunter et al., 2018; Balli et al., 2019) mainly focus on one or two variables (tourist arrivals, receipts etc.) as determinant of tourism growth. However, we attempt to conduct an-in-depth, robust and detailed analysis by using the data of eight tourism development indicators. One plausible explanation for this is justified from the reason that different tourism indicators might have different impacts on the overall economic progress and income level of people. The studied tourism development indicators include business tourism spending, tourism direct contribution to GDP, domestic tourism spending, internal travel and tourism consumption, leisure tourism spending, tourism total contribution (direct and indirect) to GDP, foreign visitors spending, and number of international tourist arrivals. The detailed inquiry of tourism-led growth hypothesis by using the maximum available data is logical and sound mind. Second, following the Solow-growth model, this study uses total final energy consumption (renewable energy and non-renewable energy) along with labor and capital as an explanatory factor for economic growth. As per the recent literature, energy consumption is considered as an important indicator for economic development, because energy is being used in every aspect of human life especially for industrialization and urbanization purpose. The primary energy use of European countries in 2017 was 15,61 million tons of oil equivalent (Mtoe), and the final energy consumption was 1,222 Mtoe,

\footnotetext{
${ }^{1}$ Economic growth and income level might be improved through the reallocation of resources from the least efficient domestic sectors of the economy towards the tourism sector.
} 
with an increase of $1 \%$ from the previous year (Simon , 2019). Lastly, this study is first in literature which uses the common correlated effects (CCE) and augmented mean group (AMG) estimators in tourism literature for robust and in-depth analysis. To the best of authors knowledge, this is the first study which employment these techniques in tourism literature: the $\mathrm{CCE}$ and $\mathrm{AMG}$ estimation techniques are considered as more reliable for valid empirics in panel data, because these techniques account for cross sectional dependence in data and help to avoid the heterogeneity and endogeneity issues. As per aforementioned facts, this article aims to contribute in tourism-economic literature by reporting more conclusive and robust evidence of tourism-led growth hypothesis as compared to those of fragmented and inconclusive findings.

\section{Background Literature}

During the past few years, the has been extensive debate on the issue of tourism industry and economic development and researchers have provided diverse findings concerning tourism economics literature (Balaguer and Cantavella-Jordá, 2002; Durbarry, 2004; Liu et al., 2015; Liu et al., 2015; Bhorat, Cassim and Tseng, 2016; Rivera, 2017; Dogru and Bulut, 2018; Shahzad et al., 2019). The existing literature mainly focused on one research question: the extent to which tourism development contribute for economic growth.

Notably, the policymakers and researchers have examined the tourism and economic growth linkages in particular countries or regions. In existing literature, several studies support the bidirectional causality between tourism and economic growth (Lee and Chang, 2008; Tang and Tan, 2013; Ivanov and Webster, 2013; Ongan, 2016; Brida, Lanzilotta and Pizzolon, 2016; Mitra, 2019), while some studies found no causality between tourism and economic growth (Tugcu, 2014; Merida and Golpe, 2016). In the tourism economics literature, the research scientists and policymakers mainly proposed four narratives: tourism-led growth, conservation, feedback, and neutrality hypotheses. These hypotheses have been proved by different research scholars for different countries in different time span. Accordingly, the present study extends the literature by incorporating eight key indicators of tourism in objective to report the robust and 
conclusive findings for the case of 34 European countries. Further, this study aims to explore tourism-economy linkage to provide fruitful policy implications.

Lee and Chang, (2008) investigated the contribution of tourism industry towards economic development for the case of OECD and non-OECD countries. The paper used panel cointegration and panel causality techniques for empirical analysis. Empirically, the study opined that uni-directional relationship exists from tourism to economic growth for OECD countries and bi-directional relationship is confirmed for the case of non-OECD countries. Romero and Molina (2013) theoretically analyzed the in-depth literature regarding tourism and economic growth for developing and developed countries. The paper argued that empirical results of previous studies are sensitive for time series, panel data and cross-sectional data, depending on the developing, emerging or developed economy. From a sample of 87 papers, the authors noted that in most of the cases, unidirectional relationship exists from tourism towards economic growth. Chou, (2013) examined the role of tourism development in an economy by using the data of 10 transition countries from 1988 to 2011. The study finds that tourism led growth hypothesis holds for the case of Latvia, Cyprus, and Slovakia while reverse relationships exist for Czech Republic and Poland. Brida, Lanzilotta and Pizzolon, (2016) examined the tourism effects on economic growth for the case of Argentina and Brazil. The study finds that tourism led growth hypothesis is valid for the case of Brazil, and there is a presence of non-linearity.

Ongan, (2016) researched the role international tourism receipts for the long-term economic growth of Turkey by using the quarterly data from 1980Q1-2004Q2. The empirical outcomes identified the presence of a feedback relationship between tourism and economic growth in the short run and long-run periods. Shahzad et al., (2017) examined the validity of tourism led growth hypothesis for top 10 transition countries in the world. By employing the quantile on the quantile approach, the paper finds strong empirical evidence in favor of 8 countries and weak linkages for the case of China and Germany.

In fact, the relationships between tourism and emissions have been found to impact heavily on carbon emissions. This is associated with the fact that industrial and 
human activities increase as tourists arrivals increases. There is a one way causal relationship from tourism to carbon dioxide emissions and between real GDP and energy consumption. Also, a two-way causal relationship between tourism and urbanization. This means that countries that depend on tourism, the behavior of $\mathrm{CO} 2$ emissions, real GDP and energy consumption can be predicted by the volume of tourist's arrivals of that country, (Adedoyin \& Bekun, 2020). Increased energy consumption may prevent tourists from visiting or reducing visits to countries that depends heavily on energy consumption and tourist visits.

Similarly, international tourism receipts impacts economic growth and vice versa and this indicates the need to ensure dynamic tourism environment. Also, the tourism-led growth hypotheses and the agriculture-led growth hypotheses are valid and implying that both tourism and agriculture sector are necessary for growth. The implication of this is that tourism alone may not be enough for sustaining economic growth and making the complementary effect of tourism and agriculture obvious, (Udom, Festus, \& Bekun, 2019).

On another note, democracy clearly is required for the equitable distribution of economic largesse, or equitable redistribution in the absence of economic growth. Nondemocracies apparently recognized some of the difficulties in maintaining environmental protection in the face of scarcity, inequality, and potential political violence. The case for a positive relationship between democracy and environmental protection has had strong support and showing a uniform relationship between democracy and the environment. Three indicators i.e deforestation, $\mathrm{CO} 2$ emissions, and soil erosion by water, shows significant negative relationships between democracy and environmental preservation. This implies, of course, that development in general and economic development, in particular, are highly relevant to environmental issues, (Midlarsky, 2016).

Perles- Ribes et al., (2017) analyzed the heterogeneous impacts of the economic crisis on tourism led growth for the case of Spain. By employing the Autoregressive Distributed Lag Model (ARDL) and Toda-Yamamoto procedure techniques, the study confirmed that the development of tourism industry positively contributes to economic growth. Li, Jin and Shi, (2018) analyzed the detailed and comprehensive literature by 
studying 346 paper of 11 tourism journals. The study pointed out three main findings; (i) tourism growth positively contribute for economic output in most of the cases, (ii) by increasing the earning and government revenue tourism industry help to mitigate poverty, (iii) the labor, capital, revenues and environment are identified as key determinants for tourism efficiency and productivity. Fahimi et al., (2018) studied the economic contribution of of the tourism sector for economic development for microstates covering the data from 1995-2015. By using the diverse empirical methodologies, the paper finds evidence in favor of tourism-induced growth and tourism-induced human capital development.

Aratuo and Etienne, (2019) researched the relationship between economic development and six indicators of tourism growth for the United States. In empirical analysis, the study used the annual data from 1998 to 2017 and employed the Autoregressive Distributed Lag Model (ARDL) and Toda-Yamamoto techniques. The empirical findings suggested that the investments in the tourism industry might contribute to long term economic progress during the periods of economic stagnation. While, empirical outcomes for short-run mentioned that tourism investments could benefit from economic development, food and hotels industry. Liu and $\mathrm{Wu},(2019)$ opined that the productivity of inbound tourism helps to boost the economy and due to an increase in economic development tourism industry improves. Mitra, (2019) re-examined the relationship between tourism development and economic growth for 158 countries. The article confirmed the bivariate casual relationships of tourism and economic growth for low GDP, middle GDP and high GDP countries. Table 2 describes the summary of recent studies on tourism led growth hypothesis from 2013 to 2019.

The third section of this paper illustrates the information of data sources, empirical models and econometric techniques. Section four discusses the empirical analysis with detailed discussion and economic reasons concerning the tourism led growth for European countries. Lastly, the final section reports the summary of findings and innovative policies drawn from empirical outcomes and logical arguments.

Table 2: Literature review on the tourism-led growth hypothesis from 2013-2019

\begin{tabular}{|l|l|l|l|l}
\hline Study & Timespan & Countries & Methods & Results and conclusions \\
\hline
\end{tabular}




\begin{tabular}{|c|c|c|c|c|}
\hline Study & Timespan & Countries & Methods & Results and conclusions \\
\hline $\begin{array}{l}\text { Tang and } \\
\text { Tan, (2013) }\end{array}$ & 1995-2009 & 12 markets of Malaysia & $\begin{array}{l}\text { Unit root tests and } \\
\text { Johansen cointegration } \\
\text { test }\end{array}$ & $\begin{array}{l}\text { Tourism led growth (tourist } \\
\text { arrivals) }\end{array}$ \\
\hline $\begin{array}{l}\text { Romero and } \\
\text { Molina, } \\
\text { (2013) }\end{array}$ & $\begin{array}{l}\text { Review } \\
\text { study }\end{array}$ & $\begin{array}{l}\text { Developed and } \\
\text { developing countries }\end{array}$ & $\begin{array}{l}\text { Time series, cross } \\
\text { sectional and panel } \\
\text { data literature }\end{array}$ & $\begin{array}{l}55 \text { studies pointed uni- } \\
\text { directional relationship and } \\
16 \text { studies identified } \\
\text { bidirectional relationships } \\
\text { between tourism and } \\
\text { growth }\end{array}$ \\
\hline $\begin{array}{l}\text { Ivanov and } \\
\text { Webster, } \\
\text { (2013) }\end{array}$ & $2000-2010$ & $\begin{array}{l}\text { China, India, USA, } \\
\text { France, Italy }\end{array}$ & Bivariate regressions & $\begin{array}{l}\text { Tourism led growth } \\
\text { hypothesis does not exist. }\end{array}$ \\
\hline $\begin{array}{l}\text { Kristo, } \\
\text { (2014) }\end{array}$ & $\begin{array}{l}\text { 1989Q1- } \\
\text { 2009Q4 }\end{array}$ & Albania & $\begin{array}{l}\text { Johansen cointegration } \\
\text { test, VECM, Variance } \\
\text { decomposition }\end{array}$ & Tourism led growth \\
\hline $\begin{array}{l}\text { Yang and } \\
\text { Fik, (2014) }\end{array}$ & $2002-2010$ & $\begin{array}{l}342 \text { prefectural level } \\
\text { cities in China }\end{array}$ & $\begin{array}{l}\text { Spatial spill-over and } \\
\text { Spatial heterogeneity }\end{array}$ & $\begin{array}{l}\text { Tourism led growth } \\
\text { feedback relationship } \\
\text { (inbound and domestic } \\
\text { tourism growth) }\end{array}$ \\
\hline $\begin{array}{l}\text { Solarin, } \\
\text { (2014) }\end{array}$ & $1980-2011$ & $\begin{array}{l}10 \text { major tourism } \\
\text { markets of developed } \\
\text { nations }\end{array}$ & $\begin{array}{l}\text { Toda Yamamoto } \\
\text { (1995), Dolado and } \\
\text { Lutkepohl (1996) }\end{array}$ & $\begin{array}{l}\text { Tourism led growth for } \\
6 / 10 \text { of the markets }\end{array}$ \\
\hline $\begin{array}{l}\text { Antonakakis, } \\
\text { Dragouni and } \\
\text { Filis, (2015) }\end{array}$ & 1996-2012 & $\begin{array}{l}\text { Italy, Germany, } \\
\text { Portugal, Spain, Austria } \\
\text { and Greece }\end{array}$ & Spillover methods & Tourism led growth \\
\hline $\begin{array}{l}\text { Trang, } \\
\text { (2015) }\end{array}$ & $1992-2011$ & Vietnam & $\begin{array}{l}\text { Growth decomposition } \\
\text { methodology }\end{array}$ & Tourism led growth \\
\hline $\begin{array}{l}\text { Ertugrul and } \\
\text { Mangir, } \\
\text { (2015) }\end{array}$ & $\begin{array}{l}\text { 1998Q1- } \\
\text { 2011Q3 }\end{array}$ & Turkey & $\begin{array}{l}\text { ARDL, Kalman filter } \\
\text { method }\end{array}$ & Tourism led growth \\
\hline $\begin{array}{l}\text { Bassil, et al., } \\
\text { (2015) }\end{array}$ & $\begin{array}{l}\text { Jan } 1995- \\
\text { May } 2013\end{array}$ & Lebanon & $\begin{array}{l}\text { VAR modelling, } \\
\text { Granger causality }\end{array}$ & Tourism led growth \\
\hline $\begin{array}{l}\text { Chiu et al., } \\
\text { (2015) }\end{array}$ & $\begin{array}{l}\text { 1994Q1- } \\
\text { 2013Q4 }\end{array}$ & China & $\begin{array}{l}\text { Johansen's } \\
\text { cointegration, VECM }\end{array}$ & Tourism led growth \\
\hline $\begin{array}{l}\text { Tang and } \\
\text { Tan, (2015) }\end{array}$ & $1974-013$ & Malaysia & $\begin{array}{l}\text { Johansen cointegration } \\
\text { test }\end{array}$ & Tourism led growth \\
\hline $\begin{array}{l}\text { Fauzel and } \\
\text { Sannassee, } \\
(2016)\end{array}$ & 1984-2014 & Mauritius & Dynamic VECM & $\mathrm{T} \leftarrow>\mathrm{G}$ \\
\hline Aslan, (2016) & $\begin{array}{l}\text { Q1:2003- } \\
\text { Q4:2012 }\end{array}$ & Turkey & ARDL & $\begin{array}{l}\mathrm{T} \leftarrow>\text { FOE for } \\
\text { accommodation, sporting } \\
\text { activities, gift expenditure, } \\
\text { Tourism led growth for } \\
\text { transport expenditures }\end{array}$ \\
\hline $\begin{array}{l}\text { Tang, Tiwari } \\
\text { and Shahbaz, } \\
(2016)\end{array}$ & $1971-2012$ & India & $\begin{array}{l}\text { Gregory-Hansen } \\
\text { cointegration test with } \\
\text { structural break, } \\
\text { variance } \\
\text { decomposition }\end{array}$ & Tourism led growth \\
\hline
\end{tabular}




\begin{tabular}{|c|c|c|c|c|}
\hline Study & Timespan & Countries & Methods & Results and conclusions \\
\hline $\begin{array}{l}\text { Perles-Ribes } \\
\text { et al., (2017) }\end{array}$ & $1957-2014$ & Spain & $\begin{array}{l}\text { ARDL with one } \\
\text { structural break, Toda- } \\
\text { Yamamoto non- } \\
\text { causality testing }\end{array}$ & Tourism led growth \\
\hline $\begin{array}{l}\text { Shahzad et } \\
\text { al., (2017) }\end{array}$ & $\begin{array}{l}\text { Q1:1990- } \\
\text { Q4:2015 }\end{array}$ & $\begin{array}{l}\text { Top } 10 \text { tourist } \\
\text { destinations }\end{array}$ & $\begin{array}{l}\text { Quantile on quantile } \\
\text { approach }\end{array}$ & $\begin{array}{l}\text { Divergence across } \\
\text { quantiles is due to the } \\
\text { phase of the economic } \\
\text { cycle and the size of } \\
\text { tourism shocks. }\end{array}$ \\
\hline $\begin{array}{l}\text { Tang and } \\
\text { Ozturk, } \\
\text { (2017) }\end{array}$ & 1982-2011 & Egypt & $\begin{array}{l}\text { TYDL, Variance } \\
\text { decomposition analysis }\end{array}$ & $\mathrm{T} \leftarrow \mathrm{G}$ \\
\hline $\begin{array}{l}\text { Hsu, Zhang } \\
\text { and Ahmad, } \\
\text { (2017) }\end{array}$ & 1995-2011 & China (30 provinces) & $\begin{array}{l}\text { Pedroni cointegration } \\
\text { tests, FMOLS }\end{array}$ & $\begin{array}{l}\text { Tourism led growth for } 3 \\
\text { regions with bidirectional } \\
\text { causality }\end{array}$ \\
\hline $\begin{array}{l}\text { Gunter } \text { et al., } \\
\text { (2018) }\end{array}$ & $1995-2002$ & $\begin{array}{l}\text { Costa Rica, Dominican } \\
\text { Republic, El Salvador, } \\
\text { Guatemala, Honduras, } \\
\text { Nicaragua, Panama, }\end{array}$ & $\begin{array}{l}\text { Conditional beta } \\
\text { convergence estimated } \\
\text { in } 1^{\text {st }} \text { differences by } \\
\text { the Arellano and Bond } \\
\text { GMM estimator }\end{array}$ & Tourism led growth \\
\hline $\begin{array}{l}\text { Hatemi-J et } \\
\text { al., (2018) }\end{array}$ & 1995-2014 & G-7 countries & $\begin{array}{l}\text { Hatemi-J (2011) and } \\
\text { Hatemi-J et al. (2016) } \\
\text { asymmetric panel } \\
\text { causality tests }\end{array}$ & $\begin{array}{l}\text { Tourism led growth for } \\
\text { France, Germany and the } \\
\text { USA }\end{array}$ \\
\hline $\begin{array}{l}\text { Yu-chi \& } \\
\text { Lin, (2018) }\end{array}$ & $1958-2017$ & Taiwan & $\begin{array}{l}\text { Johansen cointegration } \\
\text { and modified Wald } \\
\text { causality }\end{array}$ & $\begin{array}{l}\mathrm{G} \rightarrow \mathrm{T} \text { (tourist arrivals) } \\
\mathrm{G}>\mathrm{T} \text { (tourism } \\
\text { expenditures) }\end{array}$ \\
\hline $\begin{array}{l}\text { Balli et al., } \\
\text { (2019) }\end{array}$ & 1995-2014 & $\begin{array}{l}15 \text { Mediterranean } \\
\text { countries }\end{array}$ & $\begin{array}{l}\text { Westerlund (2007) } \\
\text { cointegration, } \\
\text { Gendenbach et al. } \\
\text { (2016) cointegration }\end{array}$ & $\begin{array}{l}\text { Tourism led growth for } \\
\text { Egypt, Italy, Spain } \\
\mathrm{T} \leftarrow>\text { for Morocco and } \\
\text { Turkey }\end{array}$ \\
\hline $\begin{array}{l}\text { Kožić, } \\
\text { (2019) }\end{array}$ & 2011-2016 & $\begin{array}{l}\text { Croatia ( } 259 \text { Croatian } \\
\text { towns and } \\
\text { municipalities) }\end{array}$ & $\begin{array}{l}\text { Quasi-experimental } \\
\text { research }\end{array}$ & $\begin{array}{l}\text { Tourism development } \\
\text { positively affects human } \\
\text { capital }\end{array}$ \\
\hline $\begin{array}{l}\text { Liu and } \mathrm{Wu}, \\
\text { (2019) }\end{array}$ & $\begin{array}{l}\text { 1995Q1- } \\
\text { 2016Q4 }\end{array}$ & Spain & $\begin{array}{l}\text { Spillover methods and } \\
\text { impulse response } \\
\text { function }\end{array}$ & $\begin{array}{l}\text { Tourism led growth } \\
\text { (bidirectional) }\end{array}$ \\
\hline
\end{tabular}

\section{Materials and Methods}

\subsection{Data Specification and Model Construction}

The tourism contribution in any economy can be possible with several tourism indicators monitored and recorded by tourist organizations. In this paper, we use 8 tourism development indicators (TDI), which includes business tourism spending, tourism direct contribution to GDP, domestic tourism spending, internal travel and tourism consumption, leisure tourism spending, tourism total contribution (direct and indirect) to GDP, foreign visitors spending, and number of international tourist arrivals. 
Notably, the tourism development indicators data is drawn from World Tourism Organization, Compendium of Tourism Statistics (UNWTO, 2019). To examine the tourism led growth hypothesis, we use the GDP constant 2010 US \$ and GDP per capita constant 2010 US \$ as proxies of economic growth. Following the recent literature on tourism-growth (Balsalobre-Lorente, Driha, Bekun, and Adedoyin, 2020; Fahimi et al., 2018; Tugcu, 2014), we further employ capital, labor and total energy consumption as controlling factors. The economic growth and controlling indicators data was accessed from World Development Bank ${ }^{2}$, (2020). Table 3(a) mentions the variables details, data source and presentation in empirical form.

Following the recent studies, Balsalobre-Lorente et al., (2020); Fahimi et al., (2018); Mitra, (2019), we construct two preferred empirical models to check the TDI effects on growth for European countries. To avoid the outlier issues, all the variables are transformed into natural logarithm for econometric estimations.

Model-1:

$$
\begin{gathered}
G D P_{i, t}=f\left(C A P_{i, t}, \operatorname{LBR}_{i, t}, T_{F E C_{i, t}}, T D I_{i, t}\right) \\
G D P_{i, t}=\alpha_{0}+\beta_{1} C A P_{i, t}+\beta_{2} L B R_{i, t}+\beta_{3} T F E C_{i, t}+\beta_{4} T D I_{i, t}+\varepsilon_{i, t}
\end{gathered}
$$

Whereas, in model-1 the variables $G D P_{i, t}$ presents GDP constant 2010 US $\$, C A P_{i, t}$ shows the capital investments as gross fixed capital formation constant 2010 US \$, $L B R_{i, t}$ indicates total force, $T F E C_{i, t}$ mentions the total final energy consumption and $T D I_{i, t}$ presents tourism development indicators for country $i$ for time period $t$.

The model-2 is estimated as robustness check with the change of GDP to GDP per capita. Model-2 is estimated as;

Model-2:

$$
G D P / \text { capita }_{i, t}=\alpha_{0}+\beta_{1} C A P_{i, t}+\beta_{2} L B R_{i, t}+\beta_{3} T F E C_{i, t}+\beta_{4} T D I_{i, t}+\varepsilon_{i, t}
$$

Table 3(a): Variables Narrative and Specification

\begin{tabular}{lccc}
\hline Variables & Specification & Source & Presentation \\
\hline Dependent Variables & & &
\end{tabular}

\footnotetext{
${ }^{2}$ The total final energy consumption includes energy from renewable and non-renewable sources and data is available at Sustainable energy for all. https://databank.worldbank.org/source/sustainable-energy-for-all.
} 


\begin{tabular}{|c|c|c|c|}
\hline Economic growth & GDP (Constant 2010 US \$) & World Bank & GDP \\
\hline Economic growth & GDP per capita (Constant 2010 US \$) & World Bank & GDP/capita \\
\hline \multicolumn{4}{|l|}{ Independent Variables } \\
\hline $\begin{array}{l}\text { Tourism business } \\
\text { spending }\end{array}$ & Tourism business spending's total & UNWTO & TBS \\
\hline $\begin{array}{l}\text { Tourism direct } \\
\text { contribution }\end{array}$ & Tourism direct contribution to GDP & UNWTO & TDC \\
\hline $\begin{array}{l}\text { Domestic tourism } \\
\text { spending }\end{array}$ & Domestic tourism spending's total & UNWTO & TDS \\
\hline $\begin{array}{l}\text { Internal travel and } \\
\text { tourism consumption }\end{array}$ & $\begin{array}{l}\text { activities of resident and non-resident visitors } \\
\text { within the country }\end{array}$ & UNWTO & TIC \\
\hline $\begin{array}{l}\text { Leisure tourism } \\
\text { spending }\end{array}$ & Leisure tourism spending total & UNWTO & TLS \\
\hline $\begin{array}{l}\text { Tourism total } \\
\text { contribution }\end{array}$ & Tourism total contribution to GDP & UNWTO & TTC \\
\hline $\begin{array}{l}\text { Foreign visitors } \\
\text { spending }\end{array}$ & Foreign visitors total spending & UNWTO & TFVS \\
\hline $\begin{array}{l}\text { International tourist } \\
\text { arrivals } \\
\text { Controlling variables }\end{array}$ & Number of tourist arrivals in country & UNWTO & TA \\
\hline Capital & $\begin{array}{l}\text { Gross fixed capital formation in constant } 2010 \\
\text { US \$ }\end{array}$ & World Bank & CAP \\
\hline Labor & Total labor in country & World Bank & LAB \\
\hline $\begin{array}{l}\text { Total energy } \\
\text { consumption }\end{array}$ & $\begin{array}{l}\text { Total final energy consumption (renewable and } \\
\text { non-renewable) }\end{array}$ & World Bank & TFEC \\
\hline
\end{tabular}

Source: Authors tabulation

\subsection{Estimation Strategy}

We begin our empirical examination with descriptive analysis, cross-sectional dependence check and panel unit root testing. The descriptive statistics are checked to examine the normality and stationarity properties in data. While, following the recent literature Fahimi et al., (2018), we apply the Pesaran, (2004) cross-sectional dependence test. During past decades, the age of globalization has brought dependence on economies in one region, and the cross-sectional dependence testing helps to examine the crosssectional independence between regional economies. In addition, to check the stationarity properties in data, we utilize the CIPS panel unit root test developed by Pesaran, (2007).

To test our primary hypothesis, we utilize the Common Correlated Effect (CCE) estimator and the Augmented Mean Group (AMG) estimator techniques, which are 
relatively ignored in the tourism-economics literature. The CCE estimator can be calculated through carrying out the standard panel regressions. Here, the observed regressors get added to the dependent variable's cross-sectional means and the specific regressors of the cross-unit. Pooled Group estimator was developed to handle problems about cross-unit exclusive regressors' coefficients, and Mean Group estimator is based on the individual coefficients averages. The CCEMG estimator is evaluated as the mean of the individual slope coefficient estimates assuming there is slope heterogeneity, while the CCEP is efficient under homogeneity of the slope coefficients through cross-sectional units. More so, both the CCEMG and the CCEP estimators maintain consistency under the right sets of assumptions. Furthermore, Eberhardt and Teal (2010) introduced the Augmented Mean Group (AMG) estimator as a substitute to the Pesaran's Common Correlated Effect. Recall that in the Common Correlated Effect, the unobservable common factor is viewed as not of being of specific interest for the empirical analysis.

However, the unobservable common factor shows Total Factor Productivity (TFP) in cross-country production functions. The Augmented Mean Group (AMG) estimator, shows cross-section dependence through involving a common dynamic effect in the country regression. It is gotten the year model coefficients of a pooled regression in first differences and reveals the equal-level mean evolution of unobserved common factors through all countries. The Augmented regression model includes the cointegration relationship, that differs from one country to the country, if the unobserved common factors make up part of the country-specific cointegrating relation.

The AMG estimator is executed in three steps: A pooled regression model added with year dummies is evaluated by the first difference OLS, and the differenced year dummies coefficients are collected. They show an evaluated cross-group mean of the evolution of the unobservable TFP over term. This process is termed "the common dynamic process." Next, the group-specific model gets added with this estimated TFP process. This can happen as an obvious variable and is forced on every group member with a unit coefficient through subtraction of the estimated process from the dependent variable. Every regression model involves an intercept that depicts time-invariant fixed 
effects (TFP levels). Finally, the means of the group-specific model parameters are evaluated across the panel like the MG and CCEMG estimators.

\section{Empirical Results and Discussion}

\subsection{Preliminary analysis}

Table 3(b) summarizes the main descriptive statistics for all variables of this study over the sample period. The average values of all variables are positive and greater than 1. GDP has the highest mean value while per capita GDP had a mean above one-third of the GDP which is an indicator that growth in economy does not correspond with the population growth (Shahzad et al., 2017). Most of the variables are negatively skewed; this implies a more significant chance of decrease in the series of all variables than an increase. The kurtosis for all variables is below Gaussian distribution references of 3, which implies most variables are platykurtic except for TLS, TFVS and TA are leptokurtic. The platykurtic variables have a relatively low probability for an extreme event while the reverse holds for the leptokurtic variables.

Table 3(b): Descriptive Statistics

\begin{tabular}{lrrrrrrrrr}
\hline Variables & Obs & Mean & Std.Dev & Min & Max & p1 & p99 & Skew. & Kurt. \\
\hline GDP & 714 & 25.819 & 1.676 & 21.947 & 28.939 & 22.391 & 28.855 & -.123 & 2.205 \\
GDP/capita & 714 & 9.838 & .996 & 6.95 & 11.425 & 7.424 & 11.391 & -.69 & 2.663 \\
CAP & 714 & 24.286 & 1.676 & 20.107 & 27.33 & 20.409 & 27.245 & -.199 & 2.28 \\
LBR & 714 & 15.256 & 1.274 & 11.943 & 17.577 & 12.053 & 17.553 & -.131 & 2.686 \\
TFEC & 714 & 13.467 & 1.359 & 10.29 & 16.035 & 10.666 & 15.99 & -.177 & 2.328 \\
TBS & 714 & 7.779 & 1.618 & 3.912 & 11.298 & 4.382 & 11.131 & .248 & 2.429 \\
TDC & 714 & 8.518 & 1.748 & 2.996 & 11.847 & 4.248 & 11.779 & -.049 & 2.708 \\
TDS & 714 & 8.573 & 1.959 & 3.689 & 12.795 & 4.248 & 12.697 & .118 & 2.489 \\
TIC & 714 & 9.386 & 1.652 & 4.5 & 12.889 & 5.417 & 12.824 & .026 & 2.759 \\
TLS & 714 & 9.103 & 1.753 & 2.996 & 12.662 & 4.248 & 12.622 & -.239 & 3.247 \\
TTC & 714 & 9.65 & 1.672 & 3.912 & 12.783 & 5.161 & 12.704 & -.136 & 2.854 \\
TFVS & 714 & 8.573 & 1.467 & 3.401 & 11.134 & 4.248 & 11.017 & -.543 & 3.253 \\
TA & 714 & 15.4 & 1.523 & 9.393 & 18.246 & 11.019 & 18.172 & -.69 & 3.895 \\
\hline
\end{tabular}

Previous studies in the area of tourism that utilize panel data estimation but ignore the factors of cross-sectional dependence and heterogeneity across countries generate results that predict the future erroneously (Dogan \& Aslan, 2017). The results of cross- 
sectional dependence can guide to apply the econometric techniques for valid and robust analysis. To avoid limiting the ability of the study to forecast the future accurately and consistently the study employed the heterogeneous panel estimation techniques to test for cross-sectional dependence. The CIPS panel unit root test developed by Pesaran, (2007) can verify the homogeneity, unit root properties and cross sectional independence (Dogan \& Aslan, 2017).

The cross-sectional dependence tests for all variables reveals no cross-sectional independence. This shows the presence of heterogeneity and cross-sectional dependence for all variables of European Countries understudy. To resolve the issue of stationarity in the presence of cross-sectional dependence a for the variables understudy this study shall adopt the CIPS unit root. This unit root test is reliable despite the presence of crosssectional dependence (Pesaran, 2007).

Table 4: Findings for Cross sectional dependence test

\begin{tabular}{lllll}
\hline Variable & CD-test & p-value & Corr & abs(corr) \\
\hline GDP & $97.490^{* * *}$ & 0.000 & 0.898 & 0.898 \\
GDP/capita & $94.520^{* * *}$ & 0.000 & 0.871 & 0.871 \\
CAP & $71.770^{* * *}$ & 0.000 & 0.661 & 0.684 \\
LBR & $25.750 * * *$ & 0.000 & 0.237 & 0.715 \\
TFEC & $24.010^{* * *}$ & 0.000 & 0.221 & 0.437 \\
TBS & $44.360^{* * *}$ & 0.000 & 0.409 & 0.515 \\
TDC & $44.810^{* * *}$ & 0.000 & 0.413 & 0.544 \\
TDS & $25.660^{* * *}$ & 0.000 & 0.236 & 0.491 \\
TIC & $38.650^{* * *}$ & 0.000 & 0.356 & 0.519 \\
TLS & $26.370^{* * *}$ & 0.000 & 0.243 & 0.519 \\
TTC & $43.820^{* * *}$ & 0.000 & 0.404 & 0.554 \\
TFVS & $43.830^{* * *}$ & 0.000 & 0.404 & 0.540 \\
TA & $80.310^{* * *}$ & 0.000 & 0.740 & 0.796 \\
\hline
\end{tabular}

Note: *** denotes significance level at $1 \%$ level. The CD-test mentions to reject the null hypothesis of a crosssectional independence.

Based on the results shown in Table 5, all variables of GDP, GDP /capita, capital, labour rate and all variables of a tourism reveals except from TDS and TTC are nonstationary at level, but all variables are stationary at first difference. Having confirmed the stability of all variables at first difference, it can be concluded there will be a reliable, 
accurate and meaningful long-term coefficient estimate. Therefore, the variables are stable, long-run estimates are reliable, and panel data cointegration will not be necessary.

Table 5: Findings from panel CIPS unit root test

\begin{tabular}{|c|c|c|c|c|}
\hline & Level & & First difference & \\
\hline Variable & CIPS-statistic & critical value & CIPS-statistic & critical value \\
\hline GDP & -2.335 & -2.58 & $-3.959 * * *$ & -2.63 \\
\hline GDP/capita & -1.794 & -2.58 & $-2.640^{*}$ & -2.60 \\
\hline CAP & -2.266 & -2.65 & $-3.230 * * *$ & -2.85 \\
\hline LBR & -2.375 & -2.78 & $-5.075 * * *$ & -2.85 \\
\hline TFEC & -2.567 & -2.78 & $-4.524 * * *$ & -2.71 \\
\hline TBS & -2.427 & -2.65 & $-4.758 * * *$ & -2.78 \\
\hline TDC & -2.349 & -2.78 & $-4.137 * * *$ & -2.85 \\
\hline TDS & $-2.757 * *$ & -2.65 & $-4.077 * * *$ & -2.85 \\
\hline TIC & -2.264 & -2.78 & $-3.964 * *$ & -2.71 \\
\hline TLS & -2.412 & -2.65 & $-4.014 * * *$ & -2.85 \\
\hline TTC & $-2.811^{* * *}$ & -2.78 & $-4.239 * * *$ & -2.85 \\
\hline TFVS & -2.203 & -2.78 & $-4.388^{* * *}$ & -2.85 \\
\hline $\mathrm{TA}$ & -2.111 & -2.78 & $-4.012 * *$ & -2.71 \\
\hline
\end{tabular}

Note: $* * *, * * *$ implies the rejection of the null hypothesis of a unit root at the $1 \%, 5 \%$ and $10 \%$ significance level.

\subsection{Long-run Economic growth (GDP) elasticities}

This study utilizes the Common Correlated Effect (CCE) and Augmented Mean Group (AMG) estimators to determine the values of long-run relationships between exogenous and endogenous variables (Balli et al., 2019). The estimation techniques are verifying the pattern of the variables in the long-run. The analysis as illustrated in Table 6 computed the long-run coefficients for $\mathrm{CCE}$ and AMG estimators for all variables to identify the values of each variable will have concerning GDP and GDP per capita. Overall, there is a positive relationship between tourism, labour, capital and GDP and this is similar to the findings of $\mathrm{Li}$, Jin and Shi, (2018). The elasticities of variables have positively significant values for the long run to GDP and GDP per capita. Both methods have quite a similar result for most variables stating that an increase in each of the variables will have a boost GDP. Furthermore, the magnitude of the effect each variable is to be discussed for Table 6. For tourism indicators, the result suggests that a unit change in these indicators will 
increase GDP by not more than 0.06 using CCE. Further, the AMG empirics indicates that a unit change tourism indicator will boost GDP maximally with 0.07 . In other words, if any of the independent variables rises by 10,000-unit GDP will increase by 600-700 as proven by CCE and AMG, respectively.

Table 7 analyzing the impact of tourism indicators the result suggests that a percent change in these indicators will increase GDP per capita by not more than $0.07 \%$ using CCE. In contrast, AMG suggests that a percent change tourism indicator will boost GDP per capita by $0.07 \%$ at the minimum. For instance, CCE states that a unit change in total final energy consumption will lead to 0.12 growth in the economy while AMG states that a unit change in total final energy consumption will lead to 0.22 growth in the economy. The reason for this is the insignificant growth in GDP compared to growth in population. This result is similar to the findings of (Balli et al., 2019) that revenue of tourism increases economic growth.

The CCE empirics state that a unit change in total final energy consumption will lead to 0.12 growth in the economy while AMG states that a unit change in total final energy consumption will lead to 0.22 growth in the economy. A unit change in total final energy consumption will lead to an increase GDP per capital by 0.13 and 0.24 for CCE and AMG.

\section{Robustness Check}

Table 8 suggest that all exogenous variable has a positive impact on the long-run economic growth when panel FMOLS was utilized to understudy the elasticities of long-run economic growth through other variables. In general, panel FMOLS shows that the changes in the variables lead to a proportional change in GDP. The result shows that capital, labour, and other tourism indicators have a positive impact on economic growth except for international tourist arrivals that has a negative coefficient. The check of the effects of exogenous variables on endogenous variables is to validate the robustness of CCE and AMG technique. The results of panel FMOL in accessing the extent of impact exogenous variables will have on endogenous is similar for all test technique previously utilized. This attests to the fact that the results for this test are reliable and robust. 
The table shows that capital has a positive impact on GDP in European countries. So, it could be stated that capital triggers economic growth boom while capital does not have any significant effect on it. On the flip side, it could be concluded that a one percent increase in capital will yield a $0.29 \%$ in GDP. There is a positive impact of labour on GDP in the European Union. The component of tourism indicator has a positive coefficient except for tourist arrival with a negative coefficient. This indicates that a one-unit change in any of the tourism indicators will result to 0.05 increase in GDP. Although, tourist arrival has a $1 \%$ significant negative impact on GDP. This implies that is the number of tourists' arrival for a year increases by one million; economic growth will boost by ten thousand. In conclusion, capital and other tourism indicators aside from tourist arrival and labour boost the economy of European states. 
Table 6: Long-run economic growth (GDP) elasticities using CCE and AMG estimators

\begin{tabular}{|c|c|c|c|c|c|c|c|c|c|c|c|c|c|c|c|c|}
\hline & Coef. & Prob. & Coef. & Prob. & Coef. & Prob. & Coef. & Prob. & Coef. & Prob. & Coef. & Prob. & Coef. & Prob. & Coef. & Prob. \\
\hline \multicolumn{17}{|c|}{ Common correlated effects (CCE) estimator } \\
\hline CAP & $0.195 * * *$ & 0.000 & $0.188 * * *$ & 0.000 & $0.189 * * *$ & 0.000 & $0.183 * * *$ & 0.000 & $0.186 * * *$ & 0.000 & $0.189 * * *$ & 0.000 & $0.195 * * *$ & 0.000 & $0.193 * * *$ & 0.000 \\
\hline LBR & $0.311 * *$ & 0.019 & $0.292 * *$ & 0.041 & $0.340^{* *}$ & 0.042 & $0.297 * *$ & 0.026 & $0.411^{* *}$ & 0.026 & $0.188^{*}$ & 0.093 & $0.274 * * *$ & 0.010 & $0.416^{*}$ & 0.065 \\
\hline TFEC & $0.120 * * *$ & 0.000 & $0.118 * * *$ & 0.000 & $0.159 * * *$ & 0.000 & $0.134 * * *$ & 0.000 & $0.194 * * *$ & 0.000 & $0.138 * * *$ & 0.000 & $0.150 * * *$ & 0.000 & $0.191 * * *$ & 0.000 \\
\hline TBS & 0.013 & 0.240 & & & & & & & & & & & & & & \\
\hline TDC & & & $0.063 * * *$ & 0.001 & & & & & & & & & & & & \\
\hline TDS & & & & & $0.059 * * *$ & 0.000 & & & & & & & & & & \\
\hline TIC & & & & & & & $0.058 * * *$ & 0.003 & & & & & & & & \\
\hline TLS & & & & & & & & & $0.049 * * *$ & 0.002 & & & & & & \\
\hline TTC & & & & & & & & & & & $0.041 * * *$ & 0.006 & & & & \\
\hline TFVS & & & & & & & & & & & & & $0.024 *$ & 0.059 & & \\
\hline TA & & & & & & & & & & & & & & & 0.018 & 0.245 \\
\hline Constant & 0.622 & 0.924 & -2.480 & 0.775 & -1.482 & 0.836 & -3.317 & 0.721 & -4.845 & 0.614 & -0.710 & 0.932 & 1.467 & 0.843 & -4.358 & 0.601 \\
\hline Trend & -0.001 & 0.720 & 0.000 & 0.998 & 0.001 & 0.708 & -0.001 & 0.831 & 0.000 & 0.974 & 0.001 & 0.720 & 0.002 & 0.506 & -0.002 & 0.696 \\
\hline \multicolumn{17}{|c|}{ Augmented mean group (AMG) estimator } \\
\hline CAP & $0.197 * * *$ & 0.000 & $0.188 * * *$ & 0.000 & $0.206 * * *$ & 0.000 & $0.195 * * *$ & 0.000 & $0.195 * * *$ & 0.000 & $0.191 * * *$ & 0.000 & $0.192 * * *$ & 0.000 & $0.193 * * *$ & 0.000 \\
\hline LBR & 0.099 & 0.537 & 0.131 & 0.347 & -0.010 & 0.946 & 0.063 & 0.657 & 0.096 & 0.498 & 0.067 & 0.642 & 0.055 & 0.706 & 0.044 & 0.787 \\
\hline TFEC & $0.219 * * *$ & 0.000 & $0.204 * * *$ & 0.000 & $0.209 * * *$ & 0.000 & $0.212 * * *$ & 0.000 & $0.222 * * *$ & 0.000 & $0.212 * * *$ & 0.000 & $0.212 * * *$ & 0.000 & $0.217 * * *$ & 0.000 \\
\hline TBS & $0.024 * * *$ & 0.009 & & & & & & & & & & & & & & \\
\hline TDC & & & $0.070 * * *$ & 0.000 & & & & & & & & & & & & \\
\hline TDS & & & & & $0.061 * * *$ & 0.000 & & & & & & & & & & \\
\hline TIC & & & & & & & $0.068 * * *$ & 0.000 & & & & & & & & \\
\hline TLS & & & & & & & & & $0.052 * * *$ & 0.000 & & & & & & \\
\hline TTC & & & & & & & & & & & $0.063 * * *$ & 0.000 & & & & \\
\hline TFVS & & & & & & & & & & & & & $0.034 * * *$ & 0.003 & & \\
\hline TA & & & & & & & & & & & & & & & 0.027 & 0.149 \\
\hline Constant & $16.224 * * *$ & 0.000 & $15.800 * * *$ & 0.000 & $17.582 * * *$ & 0.000 & $16.518 * * *$ & 0.000 & $16.072 * * *$ & 0.000 & $16.695 * * *$ & 0.000 & $17.041 * * *$ & 0.000 & $16.967 * * *$ & 0.000 \\
\hline Trend & 0.001 & 0.815 & 0.000 & 0.955 & 0.001 & 0.772 & 0.001 & 0.617 & 0.001 & 0.743 & 0.001 & 0.766 & 0.001 & 0.753 & 0.001 & 0.551 \\
\hline
\end{tabular}


Table 7: Long-run economic growth (GDP per capita) elasticities using CCE and AMG estimators

\begin{tabular}{|c|c|c|c|c|c|c|c|c|c|c|c|c|c|c|c|c|}
\hline & Coef. & Prob. & Coef. & Prob. & Coef. & Prob. & Coef. & Prob. & Coef. & Prob. & Coef. & Prob. & Coef. & Prob. & Coef. & Prob. \\
\hline \multicolumn{17}{|c|}{ Common correlated effects (CCE) estimator } \\
\hline CAP & $0.199 * * *$ & 0.000 & $0.188 * * *$ & 0.000 & $0.191 * * *$ & 0.000 & $0.182 * * *$ & 0.000 & $0.188 * * *$ & 0.000 & $0.194 * * *$ & 0.000 & $0.193 * * *$ & 0.000 & $0.197 * * *$ & 0.000 \\
\hline LBR & 0.233 & 0.137 & 0.182 & 0.276 & 0.236 & 0.233 & 0.196 & 0.225 & 0.315 & 0.145 & 0.098 & 0.486 & 0.173 & 0.185 & 0.326 & 0.186 \\
\hline TFEC & $0.126 * * *$ & 0.000 & $0.116^{* * * *}$ & 0.001 & $0.166 * * *$ & 0.000 & $0.140 * * *$ & 0.000 & $0.201 * * *$ & 0.000 & $0.133 * * *$ & 0.000 & $0.164 * * *$ & 0.000 & $0.196 * * *$ & 0.000 \\
\hline TBS & 0.015 & 0.256 & & & & & & & & & & & & & & \\
\hline TDC & & & $0.065 * * *$ & 0.001 & & & & & & & & & & & & \\
\hline TDS & & & & & $0.063 * * *$ & 0.000 & & & & & & & & & & \\
\hline TIC & & & & & & & $0.065 * * *$ & 0.001 & & & & & & & & \\
\hline TLS & & & & & & & & & $0.056 * * *$ & 0.001 & & & & & & \\
\hline TTC & & & & & & & & & & & $0.032 * *$ & 0.038 & & & & \\
\hline TFVS & & & & & & & & & & & & & $0.025 *$ & 0.063 & & \\
\hline TA & & & & & & & & & & & & & & & 0.015 & 0.401 \\
\hline Constant & 0.189 & 0.978 & -2.701 & 0.744 & -3.994 & 0.585 & -3.600 & 0.688 & -9.036 & 0.324 & -2.065 & 0.796 & -1.761 & 0.799 & -6.839 & 0.408 \\
\hline Trend & -0.001 & 0.771 & 0.001 & 0.878 & 0.001 & 0.786 & 0.000 & 0.986 & 0.000 & 0.953 & 0.001 & 0.755 & 0.003 & 0.478 & -0.001 & 0.801 \\
\hline \multicolumn{17}{|c|}{ Augmented mean group (AMG) estimator } \\
\hline CAP & $0.208 * * *$ & 0.000 & $0.198 * * *$ & 0.000 & $0.215^{* * *}$ & 0.000 & $0.203 * * *$ & 0.000 & $0.202 * * *$ & 0.000 & $0.201 * * *$ & 0.000 & $0.200 * * *$ & 0.000 & $0.195 * * *$ & 0.000 \\
\hline LBR & -0.074 & 0.673 & -0.036 & 0.821 & -0.174 & 0.294 & -0.104 & 0.500 & -0.065 & 0.669 & -0.108 & 0.523 & -0.106 & 0.479 & -0.126 & 0.482 \\
\hline TFEC & $0.240 * * *$ & 0.000 & $0.219 * * *$ & 0.000 & $0.233 * * *$ & 0.000 & $0.234 * * *$ & 0.000 & $0.242 * * *$ & 0.000 & $0.234 * * *$ & 0.000 & $0.234 * * *$ & 0.000 & $0.239 * * *$ & 0.000 \\
\hline TBS & $0.025^{* *}$ & 0.011 & & & & & & & & & & & & & & \\
\hline TDC & & & $0.072 * * *$ & 0.000 & & & & & & & & & & & & \\
\hline TDS & & & & & $0.062 * * *$ & 0.000 & & & & & & & & & & \\
\hline TIC & & & & & & & $0.072 * * *$ & 0.000 & & & & & & & & \\
\hline TLS & & & & & & & & & $0.057 * * *$ & 0.001 & & & & & & \\
\hline TTC & & & & & & & & & & & $0.064 * * *$ & 0.000 & & & & \\
\hline TFVS & & & & & & & & & & & & & $0.035 * *$ & 0.011 & & \\
\hline TA & & & & & & & & & & & & & & & $0.041 *$ & 0.066 \\
\hline Constant & 2.384 & 0.384 & 1.977 & 0.428 & 3.668 & 0.158 & 2.650 & 0.270 & 2.162 & 0.385 & 2.910 & 0.260 & 3.093 & 0.182 & 3.104 & 0.267 \\
\hline Trend & 0.000 & 0.897 & 0.000 & 0.982 & 0.000 & 0.953 & 0.001 & 0.766 & 0.000 & 0.887 & 0.000 & 0.843 & 0.000 & 0.873 & 0.001 & 0.803 \\
\hline
\end{tabular}


Table 8: Long-run economic growth (GDP) elasticities using grouped-mean (panel FMOLS) estimator (Robustness Check)

\begin{tabular}{|c|c|c|c|c|c|c|c|c|c|c|c|c|c|c|c|c|}
\hline Variable & Coef. & Prob. & Coef. & Prob. & Coef. & Prob. & Coef. & Prob. & Coef. & Prob. & Coef. & Prob. & Coef. & Prob. & Coef. & Prob. \\
\hline CAP & $0.290 * * *$ & 0.000 & $0.283 * * *$ & 0.000 & $0.294 * * *$ & 0.000 & $0.292 * * *$ & 0.000 & $0.293 * * *$ & 0.000 & $0.283 * * *$ & 0.000 & $0.286^{* * *} *$ & 0.000 & $0.301 * * *$ & 0.000 \\
\hline LBR & 0.094 & 0.123 & $0.191 * * *$ & 0.001 & 0.068 & 0.250 & $0.110^{*}$ & 0.053 & 0.106 & 0.119 & $0.162 * * *$ & 0.005 & $0.173 * * *$ & 0.008 & 0.087 & 0.244 \\
\hline TFEC & $0.266^{* * *}$ & 0.000 & $0.245^{* * *}$ & 0.000 & $0.271 * * *$ & 0.000 & $0.252 * * *$ & 0.000 & $0.262 * * *$ & 0.000 & $0.261 * * *$ & 0.000 & $0.240 * * *$ & 0.000 & $0.277 * * *$ & 0.000 \\
\hline TBS & $0.020 * * *$ & 0.000 & & & & & & & & & & & & & & \\
\hline TDC & & & $0.056^{* * *}$ & 0.000 & & & & & & & & & & & & \\
\hline TDS & & & & & $0.045 * * *$ & 0.000 & & & & & & & & & & \\
\hline TIC & & & & & & & $0.045^{* * *}$ & 0.000 & & & & & & & & \\
\hline TLS & & & & & & & & & $0.039 * * *$ & 0.000 & & & & & & \\
\hline TTC & & & & & & & & & & & $0.044 * * *$ & 0.000 & & & & \\
\hline TFVS & & & & & & & & & & & & & $0.022 * * *$ & 0.002 & & \\
\hline $\mathrm{TA}$ & & & & & & & & & & & & & & & -0.010 & 0.313 \\
\hline
\end{tabular}




\section{Discussion and Concluding Remarks}

This article aims to explore the relevance of tourism and its impact on economic growth in European countries by using the data of 8 variables for tourism to ensure the robustness of findings. The contributions of this paper to the academic literature are; (i) confirmation of tourism led growth hypothesis for European countries, and (ii) analyzing the heterogeneous impacts of final energy consumption (renewable and non-renewable), capital and labor on economic growth, for designing innovative policy recommendations. The empirical analysis outlines the structural effects of the tourism sector, and how capital, labor and energy consumption are related to the economic progress of countries. The investigation into tourism-growth hypothesis by analyzing the data of 8 tourism variables is innovative and missing in the existing studies.

The existing literature on tourism-growth has documented that tourism is pivotal to economic growth (Li et al., 2018; Balsalobre-Lorente, Driha, Bekun, \& Adedoyin, 2020) in a dynamic globalized world. However, there is a need to check how the tourism sector contributes to the economic growth of Europe and the relationship between final energy consumption and economic growth. In the modern world, energy has become a pillar and key factor for production and economic growth. Hence, the need for a paradigm shift of energy usage in the tourism industry should be investigated by relevant and robust strategies from the policymakers and government officials in Europe. Meanwhile, it is important to mention that the energy usage (oil, gas, and fossil fuels etc.) has environmental consequences, and such consequences are strongly enormous to economic and tourism growth.

The detailed empirical analysis mentions that all the indicators of tourism are positively associated with economic growth and per capita GDP of sample countries. Such narrative guides that improvement in the tourism industry by making specific reforms might create stability and development. Accordingly, we can establish practical implications in line with the structural changes and innovations in the tourism sector of Europe (e.g., new technologies and facilities to reduce operational costs, subsidies to the tourism business, energy availability as per climate change) to transform the tourism industry in a more disciplined and sustainable pattern. We further argue that enhancing tourism business spending and foreign tourism spending's might be helpful to reduce the adverse effects of international tourism in Europe in the long run. 
Conclusively, this article endorses the findings of Fahimi et al., (2018) and mentions a similar narrative. The good news from this juxtaposition in terms of standard concern is the possibility of economic progress through tourism development through individual and business investments for tourism and tourist arrivals etc. Notably, we can claim that the European countries can depend on tourism sector for economic development at individual level, and such growth may not be gloomy in the future. In a general sense, the tourism sector has witnessed improvement and transformation over time. While more efforts in the future might be helpful to enhance the tourism potentials in terms of cultural and religious tourism attractions etc, this work has a sound opinion that sustainable economic and tourism policies alongside investments on energy, labor (human capital) can be a useful policy to maximize the sustainable economic growth in Europe.

The policymakers and economists should combine efforts for the betterment of the tourism industry along with the promotion of renewable energy sources. One, renewable energy utilization can fulfil the energy needs for production and consumption needs of tourism. Second, renewable energy consumption can reduce the environmental externalities and brings sustainable environment for business and tourist arrivals. In addition, the empirics of labor and capital indicate that capital investments and labor utilization can enhance the economic progress and per capita income of the population. In the same line, we can argue that capital investments in tourism sector can be a sign of economic prosperity across the European region. At this juncture, the paper recommends that future studies can investigate the in-depth relationships between tourism indicators and growth for developed and emerging economies of Europe and top tourist destinations as key samples.

\section{Acknowledgement}

The authors declare that they have no known competing financial interests or personal relationships that could have appeared to influence the work reported in this paper. No funding was received for this work. 


\section{References}

Adedoyin, F. F., \& Bekun, F. V. (2020). Modelling the interaction between tourism, energy consumption, pollutant emissions and urbanization: renewed evidence from panel VAR. Environmental Science and Pollution Research. https://doi.org/10.1007/s11356-02009869-9

Adedoyin, F. F., Nathaniel, S., \& Adeleye, N. (2020). An investigation into the anthropogenic nexus among consumption of energy, tourism, and economic growth: do economic policy uncertainties matter? Environmental Science and Pollution Research, 113.

Adedoyin, F. F., Bekun, F. V., Driha, O. M., \& Balsalobre-Lorente, D. (2020). The effects of air transportation, energy, ICT and FDI on economic growth in the industry 4.0 era: Evidence from the United States. Technological Forecasting and Social Change, 160(August), 120297. https://doi.org/10.1016/j.techfore.2020.120297

Andereck, K. L., Valentine, K. M., Knopf, R. C., \& Vogt, C. A. (2005). Residents' perceptions of community tourism impacts. Annals of Tourism Research, 32(4), 10561076. https://doi.org/10.1016/j.annals.2005.03.001

Antonakakis, N., Dragouni, M., \& Filis, G. (2015). Tourism and growth: The times they are a-changing. Annals of Tourism Research, 50, 165-169. https://doi.org/10.1016/j.annals.2014.11.008

Aratuo, D. N., \& Etienne, X. L. (2019). Industry level analysis of tourism-economic growth in the United States. Tourism Management, 70(September 2018), 333-340. https://doi.org/10.1016/j.tourman.2018.09.004

Aslan, A. (2016). Current Issues in Tourism Does tourism cause growth? Evidence from Turkey, 3500. https://doi.org/10.1080/13683500.2015.1015970

Balaguer, J., \& Cantavella-Jordá, M. (2002). Tourism as a long-run economic growth factor: The Spanish case. Applied Economics, 34(7), 877-884. https://doi.org/10.1080/00036840110058923

Balli, E., Sigeze, C., Manga, M., Birdir, S., \& Birdir, K. (2019). The relationship between tourism, $\mathrm{CO} 2$ emissions and economic growth: a case of Mediterranean countries. Asia Pacific Journal of Tourism Research, 24(3), 219-232. https://doi.org/10.1080/10941665.2018.1557717

Balsalobre-Lorente, D., Driha, O. M., Bekun, F. V., \& Adedoyin, F. F. (2020). The asymmetric impact of air transport on economic growth in Spain: fresh evidence from the tourism-led growth hypothesis. Current Issues in Tourism, 0(0), 1-17. https://doi.org/10.1080/13683500.2020.1720624

Bassil, C., Hamadeh, M., \& Samara, N. (2015). The tourism led growth hypothesis: the Lebanese case. https://doi.org/10.1108/TR-05-2014-0022 
Bhorat, H., Cassim, A., \& Tseng, D. (2016). Higher education, employment and economic growth: Exploring the interactions. Development Southern Africa, 33(3), 312-327. https://doi.org/10.1080/0376835X.2016.1161501

Bourne, R. (2016). Why did the British Brexit? and What are the Implications for Classical Liberals? Economic Affairs, 36(3), 356-363. https://doi.org/10.1111/ecaf.12205

Brida, J. G., Lanzilotta, B., \& Pizzolon, F. (2016). Dynamic relationship between tourism and economic growth in MERCOSUR countries: A nonlinear approach based on asymmetric time series models. Economics Bulletin, 36(2), 879-894.

Chiu, F. P., Kuo, H. I., Chen, C. C., \& Hsu, C. S. (2015). The energy price equivalence of carbon taxes and emissions trading-Theory and evidence. Applied Energy, 160, 164-171. https://doi.org/10.1016/j.apenergy.2015.09.022

Chou, M. C. (2013). Does tourism development promote economic growth in transition countries? A panel data analysis. Economic Modelling, 33, 226-232. https://doi.org/10.1016/j.econmod.2013.04.024

Corbet, S., O’Connell, J. F., Efthymiou, M., Guiomard, C., \& Lucey, B. (2019). The impact of terrorism on European tourism. Annals of Tourism Research, 75(December 2018), 117. https://doi.org/10.1016/j.annals.2018.12.012

Del P. Pablo-Romero, M., \& Molina, J. A. (2013). Tourism and economic growth: A review of empirical literature. Tourism Management Perspectives, 8, 28-41. https://doi.org/10.1016/j.tmp.2013.05.006

Dogan, E., \& Aslan, A. (2017). Exploring the relationship among CO2 emissions, real GDP, energy consumption and tourism in the EU and candidate countries: Evidence from panel models robust to heterogeneity and cross-sectional dependence. Renewable and Sustainable Energy Reviews, 77(February 2016), 239-245. https://doi.org/10.1016/j.rser.2017.03.111

Dogru, T., \& Bulut, U. (2018). Is tourism an engine for economic recovery? Theory and empirical evidence. Tourism Management, 67, 425-434. https://doi.org/10.1016/j.tourman.2017.06.014

Durbarry, R. (2004). Tourism and economic growth: the case of. Tourism Economics, 10(4), 389-401.

Ertugrul, H. M., \& Mangir, F. (2015). Current Issues in Tourism The tourism-led growth hypothesis: empirical evidence from 3500. https://doi.org/10.1080/13683500.2013.868409

Eberhardt, M. and Bond, S., (2009). Cross-section dependence in nonstationary panel models: A novel estimator. MPRA Paper, No. 17870, https://mpra.ub.unimuenchen.de/17870/2/MPRA_paper_17870.pdf 
Eberhardt, M., \& Teal, F. (2010). Productivity Analysis in Global Manufacturing Production.

Fahimi, A., Akadiri, S. Saint, Seraj, M., \& Akadiri, A. C. (2018). Testing the role of tourism and human capital development in economic growth. A panel causality study of micro states. Tourism Management Perspectives, 28(August), 62-70. https://doi.org/10.1016/j.tmp.2018.08.004

Fauzel, S., \& Sannassee, R. V. (2016). growth: Evidence from a small island developing state Analyzing the impact of tourism foreign direct investment on economic growth: Evidence from a small island developing state, (August). https://doi.org/10.1177/1354816616664249

Gibson, H. D., Hall, S. G., \& Tavlas, G. S. (2012). Journal of International Money The Greek financial crisis: Growing imbalances and sovereign spreads. Journal of International Money and Finance, 31(3), 498-516. https://doi.org/10.1016/j.jimonfin.2011.10.009

Gunter, U., Ceddia, M. G., ... Tröster, B. (2018). Contribution of international ecotourism to comprehensive economic development and convergence in the Central American and Caribbean region. Applied Economics, 00(00), 1-16. https://doi.org/10.1080/00036846.2018.1430339

Hatemi-J, A., Gupta, R., Kasongo, A., Mboweni, T., \& Netshitenzhe, N. (2018). Does tourism cause growth asymmetrically in a panel of G-7 countries? A short note. Empirical, 45(1), 49-57. https://doi.org/10.1007/s10663-016-9345-3

Hsu, M. K., Zhang, J., \& Ahmad, Y. (2017). Government digital information discovery and exploration: the case of unraveling tourism-led-growth paradox in China. Information Discovery and Delivery, 45(4), 212-219. https://doi.org/10.1108/IDD-10-2016-0036

Ivanov, S., \& Webster, C. (2013). Tourism's impact on growth: The Role of Globalization. Annals of Tourism Research, 41, 231-236. https://doi.org/10.1016/j.annals.2012.12.008

Jones, C., \& Li, S. N. (2015). The economic importance of meetings and conferences: A satellite account approach. Annals of Tourism Research, 52, 117-133. https://doi.org/10.1016/j.annals.2015.03.004

Kožić, I. (2019). Can tourism development induce deterioration of human capital? Annals of Tourism Research, 2018), 168-170. https://doi.org/10.1016/j.annals.2018.12.018

Kristo, J. (2014). Evaluating the Tourism-Led Economic Growth Hypothesis in a Developing Country: The Case Of Albania, 5(8), 39-51. https://doi.org/10.5901/mjss.2014.v5n8p39

Lanouar, C., \& Goaied, M. (2019). Tourism, terrorism and political violence in Tunisia: Evidence from Markov-switching models. Tourism Management, 70(September), 404418. https://doi.org/10.1016/j.tourman.2018.09.002 
Lee, C. C., \& Chang, C. P. (2008). Tourism development and economic growth: A closer look at panels. Tourism Management, 29(1), 180-192. https://doi.org/10.1016/j.tourman.2007.02.013

Li, K. X., Jin, M., \& Shi, W. (2018). Tourism as an important impetus to promoting economic growth: A critical review. Tourism Management Perspectives, 26(April 2016), 135-142. https://doi.org/10.1016/j.tmp.2017.10.002

Liu, A., \& Wu, D. C. (2019). Tourism productivity and economic growth. Annals of Tourism Research, 76(April), 253-265. https://doi.org/10.1016/j.annals.2019.04.005

Liu, A., Wu, D. C., Del P. Pablo-Romero, M., Molina, J. A., Tang, C. F., Tan, E. C., ... Lin, D. (2015). How strong is the linkage between tourism and economic growth in Europe? Annals of Tourism Research, 61(1), 135-142. https://doi.org/10.1016/j.tmp.2013.05.006

Matarrita-Cascante, D. (2010). Beyond growth. Reaching tourism-led development. Annals of Tourism Research, 37(4), 1141-1163. https://doi.org/10.1016/j.annals.2010.05.004

Merida, A., \& Golpe, A. A. (2016). The Formation of the Tourist' s Loyalty How Does It Affect Price Discounts? International Journal of Tourism Research, 9(August), 453-464. https://doi.org/10.1002/jtr

Mitra, S. K. (2019). Is tourism-led growth hypothesis still valid? International Journal of Tourism Research, (September 2018), 1-10. https://doi.org/10.1002/jtr.2285

Ohlan, R. (2017). The relationship between tourism, financial development and economic growth in India. Future Business Journal, 3(1), 9-22. https://doi.org/10.1016/j.fbj.2017.01.003

Ongan, S. (2016). The Contribution of Tourism to the Long-run Turkish Economic Growth The Contribution of Tourism to the Long-Run Turkish Economic Growth Assistant Professor Dr . Serdar Ongan Department of Economics Department of Economics, (January 2005).

Perles-Ribes, J. F., Ramón-Rodríguez, A. B., Rubia, A., \& Moreno-Izquierdo, L. (2017). Is the tourism-led growth hypothesis valid after the global economic and financial crisis? The case of Spain 1957-2014. Tourism Management, 61, 96-109. https://doi.org/10.1016/j.tourman.2017.01.003

Pesaran, M. H., 2004. General Diagnostic Tests for Cross Section Dependence in Panels. University of Cambridge, Working paper.

Pesaran, M. H. (2007). A simple panel unit root test in the presence of cross-section dependence. Journal of Applied Econometrics, 22, 265-312. https://doi.org/10.1002/jae

Pipike, J. K. (2012). Comparative Study between Fiji and Papua New Guinea Tourism Development: Lessons to Learn from Fiji. Procedia - Social and Behavioral Sciences, 65, 192-198. https://doi.org/10.1016/j.sbspro.2012.11.110 
Rivera, M. A. (2017). The synergies between human development, economic growth, and tourism within a developing country: An empirical model for Ecuador. Journal of Destination Marketing and Management, 6(3), 221-232. https://doi.org/10.1016/j.jdmm.2016.04.002

Severn, A. K. (1968). Exports and Economic Growth. Kyklos, 21(3), 546-548. https://doi.org/10.1111/j.1467-6435.1968.tb00132.x

Simon, F., 2019. Energy consumption continues to rise in Europe: Eurostat. [Online] Available at: https://www.euractiv.com/section/energy/news/energy-consumptioncontinues-to-rise-ineuropeeurostat/\#targetText=Energy\%20consumption\%20in\%20the\%20EU, the \%20previ ous\%20year\%2C\%20Eurostat\%20said. [Accessed 29 September 2019].

Shahbaz, M., Sarwar, S., Chen, W., \& Malik, M. N. (2017). Dynamics of electricity consumption, oil price and economic growth: Global perspective. Energy Policy, 108(May), 256-270. https://doi.org/10.1016/j.enpol.2017.06.006

Shahzad, S. J. H., Shahbaz, M., Ferrer, R., \& Kumar, R. R. (2017). Tourism-led growth hypothesis in the top ten tourist destinations: New evidence using the quantile-onquantile approach. Tourism Management, 60, 223-232. https://doi.org/10.1016/j.tourman.2016.12.006

Shahzad, U., Hussain, M., Qin, F., \& Muhamadi, S. (2019). Role of FDI and Foreign Remittances in Boosting and Economic Growth: Evidence from Brazil. European Online Journal of Natural and Social Sciences, 8(1), 118-127.

Smith, H., 2016. A year after the crisis was declared over, Greece is still spiraling down. [Online] Available at: https://www.theguardian.com/business/2016/aug/13/greekeconomy-still-spiralling-down-year-after-crisis-declared-over [Accessed 29 August 2019].

Solarin, S. A. (2014). Current Issues in Tourism Global financial crisis and stationarity of tourist arrivals: evidence from Mauritius, (July 2015). https://doi.org/10.1080/13683500.2014.985639

Tang, C. F., \& Ozturk, I. (2017). Is tourism a catalyst of growth in Egypt? Evidence from Granger non-causality and the generalized variance decomposition analysis. Anatolia, 2917(May), 1-9. https://doi.org/10.1080/13032917.2017.1283635

Tang, C. F., \& Tan, E. C. (2013). How stable is the tourism-led growth hypothesis in Malaysia? Evidence from disaggregated tourism markets. Tourism Management, 37, $52-$ 57. https://doi.org/10.1016/j.tourman.2012.12.014

Tang, C. F., \& Tan, E. C. (2015). Does tourism effectively stimulate Malaysia's economic growth? Tourism Management, 46(2015), 158-163. https://doi.org/10.1016/j.tourman.2014.06.020 
Tang, C. F., Tiwari, A. K., \& Shahbaz, M. (2016). Dynamic inter-relationships among tourism, economic growth and energy consumption in India. Geosystem Engineering, 9328, 1-12. https://doi.org/10.1080/12269328.2016.1162113

Trang, M. (2015). Research note: Empirical assessment of the tourism-led growth hypothesis - the case of, (August 2014). https://doi.org/10.5367/te.2013.0307

Tugcu, C. T. (2014). Tourism and economic growth nexus revisited: A panel causality analysis for the case of the Mediterranean Region. Tourism Management, 42, 207-212. https://doi.org/10.1016/j.tourman.2013.12.007

UNWTO. (2018). UNWTO Tourism Highlights. International Tourism Trends 2017. United Nations World Tourism $\quad$ Organization, $1-20$. https://doi.org/https://doi.org/10.18111/9789284419876

UNWTO, 2019. International Tourist Arrivals Reach 1.4 billion Two Years Ahead of Forecasts. [Online] Available at: http://www2.unwto.org/press-release/2019-0121/international-tourist-arrivals-reach-14-billion-two-years-ahead-forecasts [Accessed 30 August 2019].

World Development Bank, 2020. World Development Indicators. [Online] Available at: http://databank.worldbank.org/data/reports.aspx?source=world-development-indicators\# [Accessed 15 July 2019].

WTTS, 2011. Annual Reports, Progress and Priorities 2011. [Online] Available at: https://www.wttc.org/economic-impact/country-analysis/country-reports [Accessed 29 August 2019].

Yang, Y., \& Fik, T. (2014). Spatial effects in regional tourism growth. Annals of Tourism Research, 46, 144-162. https://doi.org/10.1016/j.annals.2014.03.007

Yu-chi, S., \& Lin, H. (2018). Causality Relationship Between Tourism, Foreign Direct Investment and Economic Growth in Taiwan. Asian Journal of Economic Modelling, 6(3), 287-293. https://doi.org/10.18488/journal.8.2018.63.287.293 